\title{
Heteropterans as aphid predators in inter-mountain alfalfa
}

\author{
Xavier PONS, BeLÉn LUMBIERRES and Ramon ALBAJES \\ University of Lleida, Department of Crop and Forest Sciences, Centre UdL-IRTA, Rovira Roure 191, 25198 Lleida, Spain; \\ e-mail: xavier.pons@irta.cat
}

Key words. Orius, Nabis, mirids, Therioaphis trifolii, Acyrthosiphon pisum, Aphis craccivora, predators, coccinellids, numerical responses

\begin{abstract}
The relationships between predatory Heteroptera and their potential prey species were investigated during two crop seasons in an inter-mountain area close to the Pyrenees (Iberian Peninsula). Regression was used to analyze the potential numerical responses shown by heteropterans to aphids and other potential prey during alfalfa intercuts (the plant growth period between cuts) of high aphid occurrence. The most abundant heteropterans were Orius spp., Nabis spp. and mirids, and all were present in alfalfa stands throughout the season. Acyrthosiphon pisum was the prevalent species during the $2^{\text {nd }}$ intercut, Therioaphis trifolii during the $4^{\text {th }}$ and Aphis craccivora during the $5^{\text {th }}$. We performed simple regression analysis between the Orius sp., Nabis sp. and mirids and the prevalent aphid species, forward multiple regression analysis between heteropterans and all possible soft-bodied prey species; and both analyses for coccinellids, as relative aphid predator specialists. The heteropterans responded numerically to $\mathrm{A}$. pisum but not to T. trifolii or A. craccivora. Heteropterans also showed numerical responses to other potential prey (leafhoppers, thrips, and other soft bodied prey) that remained at low densities throughout the season. All these preys may contribute to the presence of heteropterans in alfalfa stands throughout the season. The results suggest that heteropterans may contribute to reduce A. pisum, particularly at the beginning of the growing season, and on other potential pests when they invade or recolonize alfalfa, and may help to delay or prevent the build-up of these pest populations.
\end{abstract}

\section{INTRODUCTION}

Alfalfa is the most important fodder crop in Spain and one of the most common crops participating in arable crop rotation, especially in the northeast, where winter cereals and maize are the other main crops.

To determine the relationships between pests and natural enemies in alfalfa fields in Spain, several studies have been carried out since 1994 (e.g. Núñez, 2002; Pons et al., 2005). These studies have dealt with major pest and predator occurrence and seasonal abundance, the role of alfalfa as a reservoir of natural enemies and more specifically the relationships between aphids and natural enemies. Potential insect pests include Colaspidema atrum Olivier (Coleoptera: Chrysomelidae), Hypera postica Gyllenhall (Coleoptera: Curculionidae), lepidopteran larvae (especially Helicoverpa armigera Hübner) and aphids [Acyrthosiphon pisum Harris, Aphis craccivora Koch and Therioaphis trifolii (Monell)]. Some of these pests may cause economic losses and on average 3-4 sprays of non-selective insecticides per season are applied. This extended control strategy can seriously affect natural enemies, leading to an increase in the pest incidence year after year and limiting the role of alfalfa as natural enemy reservoir for field crops. Under low or no insecticide treatment regimes, there are a great variety of natural enemies in the study area and more than 100 predatory species of Heteroptera (Anthocoridae, Nabidae, Miridae, Lygaeidae), Thysanoptera, Neuroptera (Chrysopidae, Hemerobiidae), Coleoptera (Coccinellidae, Carabidae, Staphylinidae, Cantharidae), Diptera (Syrphi- dae), and several species of spiders and other Arachnida have been recorded (Núñez, 2002; Pons et al., 2005).

Heteropteran predators are characterized as generalist (Schaefer \& Panizzi 2000). They are a major component of the arthropod fauna in both natural and managed habitats (Coll \& Ruberson, 1998) and they are regarded as relevant natural enemies of pests in agricultural systems (Ruberson \& Coll, 1998). Heteropteran predators have been identified among the primary insect predators in alfalfa fields of New York, and in California they constituted about $70 \%$ of all heteropterans found in alfalfa (Yeargan, 1998). In Spain, they represent about 50-60\% of the predators recorded in alfalfa stands (Pons et al., 2005).

Heteropterans have been successfully used as agents of biological control of pests such as whiteflies, thrips and mites (Albajes \& Alomar, 1999; Xu et al., 2006; Arnó et al., 2008), but their role as aphid predators is not clear. Most heteropteran predators are limited in their rate of population growth by relatively long generation times compared with aphids, and there is little evidence that they aggregate in high-density aphid patches. These biological trends hinder the capacity of heteropterans to keep aphid populations in check (Yeargan, 1998). However, Desneux et al. (2006) reported Orius insidiosus to be a key predator for suppression of aphids in soybeans. Because heteropterans are very abundant in alfalfa fields and remain there during most of the year (Pons et al., 2005), they may play a role in the regulation of aphid populations. However, there is very little literature dealing with this subject. 
This study was carried out in an area which is being transformed to a more intensified agricultural system: permanent pastures are being replaced by crop rotations of arable crops and alfalfa under no-till and integrated pest management systems. This crop system allowed us to investigate the effects that this transformation may have on the relationships between pests and natural enemies. In this paper we examine the relationship between heteropterans and aphids on alfalfa by analysing numerical responses. Because aphids are not the only prey for heteropterans, we also examine predator numerical response to other potential prey species. The fact that no pesticides have been applied to alfalfa since it has been extensively cultivated in the area provides a suitable environment for studying the influence of heteropterans on their potential prey.

\section{MATERIAL AND METHODS}

The study was carried out in an inter-mountain area near the Pyrenees (the Alt Urgell county, Catalonia, Spain). The alfalfa fields were at $700-800 \mathrm{~m}$ altitude, with an average rainfall of $650 \mathrm{~mm}$ per year and a mean temperature during the alfalfagrowing season of about $17^{\circ} \mathrm{C}$. In the region, alfalfa has been extensively cultivated since 2002 , when it was introduced as an alternative to natural pastures in the no-till crop rotation that included winter cereal and silage maize (Eizaguirre et al., 2005).

Four and eight fields sown with the cultivar Aragon were monitored in 2006 and 2007, respectively. Crop age ranged from 1 to 3 years, the area averaged 5 ha (range 2-12 ha) and all fields were sprinkler-irrigated. The growing season was from April to mid October and all fields underwent 5 cuttings each year, performed on the same day for all fields each year (Table 1 ). The fields were free of insecticides during the study years and had not been sprayed previously.

From April/May to September sweep-net samples were collected 2 or 3 times between cutings (Table 1). Each sample consisted of 5 sweeps of $180^{\circ}$ made with a sweep-net of $38 \mathrm{~cm}$ diameter. Each field was divided into 4 sectors and 3 samples per sector were collected. Samples were stored in an icebox and transported to the laboratory, where pests and predators were identified, distinguishing nymphs or larvae from adults when possible, and their numbers recorded. In the two years the fields were monitored on the same sampling dates.

Because alfalfa cuttings involve a temporary, but drastic, change to the system, we considered the periods of alfalfa growth between cuts (intercut hereafter) to be separate units: $1^{\text {st }}$ intercut corresponding to the period from starting growing season to the $1^{\text {st }}$ cutting, $2^{\text {nd }}$ intercut to the growing period from $1^{\text {st }}$ to the $2^{\text {nd }}$ cutting, the $3^{\text {rd }}$ intercut from the $2^{\text {nd }}$ to the $3^{\text {rd }}$ cutting and so on. Relationships between heteropterans and aphids were studied through regressional analysis shown by these predators to aphids and other potential prey during intercuts of high aphid occurrence. Correlation studies do not give cause-effect relationships but allow the association between predators and prey to be inferred (Naranjo \& Hagler, 1998), and this is an essential step towards more precise studies for estimating and quantifying predator-prey effects. Several components of the predator-prey relationships (numerical and aggregative responses, prey specificity, or even functional response components) may lead to significant immediate or lag correlations (Kidd \& Jervis, 1996). To determine whether the response was immediate or delayed, we performed the analysis with no lag and with predator abundance one sampling date lagged throughout:
TABle 1. Sampling dates and dates when the alfalfa was cut. Within the year all the fields were cut on the same day.

\begin{tabular}{|c|c|c|c|}
\hline \multicolumn{2}{|c|}{2006} & \multicolumn{2}{|c|}{2007} \\
\hline Sampling dates & Days of cut & Sampling dates & Days of cut \\
\hline & 18 April & 19 April & \\
\hline 4 May & & & 24 April \\
\hline 16 May & & 7 May & \\
\hline 26 May & & 15 May & \\
\hline & 4 June & 30 May & \\
\hline 16 June & & & 19 June \\
\hline 26 June & & 29 June & \\
\hline 6 July & & 11 July & \\
\hline & 9 July & & 17 July \\
\hline 20 July & & 23 July & \\
\hline 31 July & & 1 August & \\
\hline 10 August & & 10 August & \\
\hline & 16 August & & 21 August \\
\hline 4 September & & 30 August & \\
\hline 18 September & & 12 September & \\
\hline & 4 October & 27 September & \\
\hline & & & 9 October \\
\hline
\end{tabular}

(1) Simple regression analysis between the most abundant heteropterans and the prevalent aphid species.

(2) Forward multiple regression analysis between those heteropterans and all the recorded soft-bodied prey: prevalent and other aphid species, thrips, leafhoppers, larvae of alfalfa weevil H. postica, and other soft-bodied prey (lepidopteran larvae, collembolla and planthoppers). Because nabids can also prey on mirids (Lattin, 1989; Braman, 2000), mirids were included in the analysis of nabid numerical response (nymphs and adults for Nabis adults and nymphs only for Nabis nymphs). The significance level for inclusion of a predictor variable was set at $\alpha=$ 0.05 .

(3) Simple and multiple analyses as above for coccinellids, as relative aphid specialists, in order to compare them with the generalist heteropterans.

All statistical analyses were made using PROC REG (SAS Institute, 2000). Data for statistical analysis were transformed to $\operatorname{sqr}(\mathrm{x}+0.5)$ according to Little \& Hills (1972). Simple regression analyses were performed separately each year. In multiple regression analyses the year was included as a covariate and when it was not significant $(P>0.05)$ the analysis was performed again by pooling data from 2006 and 2007. As the catches of nymphs of Orius sp. were low (less than 0.5 individuals per 5 sweeps), they were not included in the analysis. Mirids were analyzed as a family because no separation by species or genus was made.

\section{RESULTS}

\section{Abundance of aphids and other potential prey}

Aphids were the most abundant herbivore during the study with percentages of abundance usually higher than $80 \%$, except for the $2^{\text {nd }}$ intercut period in 2007 (Table 2). Alfalfa weevil was also common during the $2^{\text {nd }}$ intercut and larvae of this species represented nearly $9 \%$ and more than $25 \%$ of total herbivores collected at that time in 2006 and 2007, respectively. Population densities of the other potential pests were much lower.

Three aphid species were recorded: Acyrthosiphon pisum, Aphis craccivora and Therioaphis trifolii. In 2006, $A$. pisum and $T$. trifolii were the prevalent species, 
TABLE 2. Mean (x, in insects $* 5$ sweeps) and relative (\%, in percentage) abundance of herbivorous insects during the $2^{\text {nd }}, 4^{\text {th }}$ and $5^{\text {th }}$ intercuts of alfalfa and during the whole alfalfa growing season in 2006 and 2007.

\begin{tabular}{|c|c|c|c|c|c|c|c|c|c|c|c|c|c|c|c|c|}
\hline \multirow{3}{*}{ Herbivore } & \multicolumn{8}{|c|}{$2006^{c}$} & \multicolumn{8}{|c|}{$2007^{d}$} \\
\hline & \multicolumn{2}{|c|}{$2^{\text {nd }}$} & \multicolumn{2}{|c|}{$4^{\text {th }}$} & \multicolumn{2}{|c|}{$5^{\text {th }}$} & \multicolumn{2}{|c|}{ Seasonal } & \multicolumn{2}{|c|}{$2^{\text {nd }}$} & \multicolumn{2}{|c|}{$4^{\text {th }}$} & \multicolumn{2}{|c|}{$5^{\text {th }}$} & \multicolumn{2}{|c|}{ Seasonal } \\
\hline & $\mathrm{x}$ & $\%$ & $\mathrm{x}$ & $\%$ & $\mathrm{x}$ & $\%$ & $\mathrm{x}$ & $\%$ & $\mathrm{x}$ & $\%$ & $\mathrm{x}$ & $\%$ & $\mathrm{x}$ & $\%$ & $\mathrm{x}$ & $\%$ \\
\hline Aphids & 174.6 & 83.2 & 255.8 & 94.8 & 106.6 & 86.0 & 144.9 & 86.3 & 38.4 & 51.1 & 260.6 & 91.9 & 164.6 & 87.6 & 122.7 & 78.4 \\
\hline Alfalfa weevil larvae & 18.2 & 8.7 & 2.4 & 0.9 & 0.28 & 0.2 & 6.8 & 4.0 & 19.9 & 26.5 & 0.17 & $<0.1$ & 0.1 & $<0.1$ & 18.6 & 11.5 \\
\hline Thrips & 6.2 & 2.9 & 2.3 & 0.8 & 1.2 & 0.9 & 5.8 & 3.5 & 6.0 & 8.0 & 7.4 & 2.6 & 5.7 & 3.0 & 7.6 & 4.7 \\
\hline Leafhoppers & 3.1 & 1.5 & 4.5 & 1.7 & 5.7 & 4.6 & 4.1 & 2.4 & 1.2 & 1.6 & 6.4 & 2.3 & 11.5 & 6.1 & 5.5 & 3.4 \\
\hline Soft-bodied $^{\mathrm{a}}$ & 1.7 & 0.8 & 1.7 & 0.6 & 3.7 & 2.9 & 2.5 & 1.5 & 1.2 & 2.0 & 2.5 & 0.9 & 2.4 & 1.3 & 2.8 & 1.7 \\
\hline Others $^{\mathrm{b}}$ & 6.0 & 2.9 & 3.1 & 1.1 & 6.6 & 5.3 & 3.8 & 2.3 & 8.1 & 10.8 & 6.4 & 2.3 & 3.6 & 1.9 & 5.4 & 3.3 \\
\hline
\end{tabular}

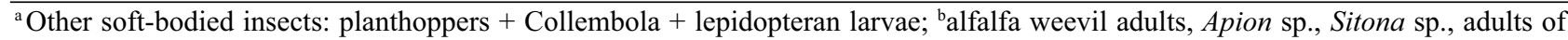
Lepidoptera and other non-soft-bodied insects; ${ }^{c}$ values of the $2^{\text {nd }}, 4^{\text {th }}$ and $5^{\text {th }}$ intercuts come from the average of 144 samples $(3$ sampling dates * 4 fields * 4 sectors/field * 3 samples/sector). Seasonal value comes from the average of 528 samples (11 sampling dates); ${ }^{\text {d }}$ Values of the $2^{\text {nd }}, 4^{\text {th }}$ and $5^{\text {th }}$ intercuts come from the average of 288 samples $(3$ sampling dates $* 8$ fields $* 4$ sectors/field $* 3$ samples/sector). Seasonal value comes from the average of 1152 samples (12 sampling dates).

whereas A. craccivora remained at very low levels (Fig. trifolii, occurred during the fourth intercut. In 2007, the 1). Seasonal abundance of aphids showed 2 peaks: the first one, composed of $A$. pisum, occurred during the second intercut and the second one, formed mainly by $T$.

pattern of the aphid seasonal abundance was similar until September, when a peak of A. craccivora was recorded (Fig. 1).

A 2006 $\longleftrightarrow 4^{\text {th }}$ intercut
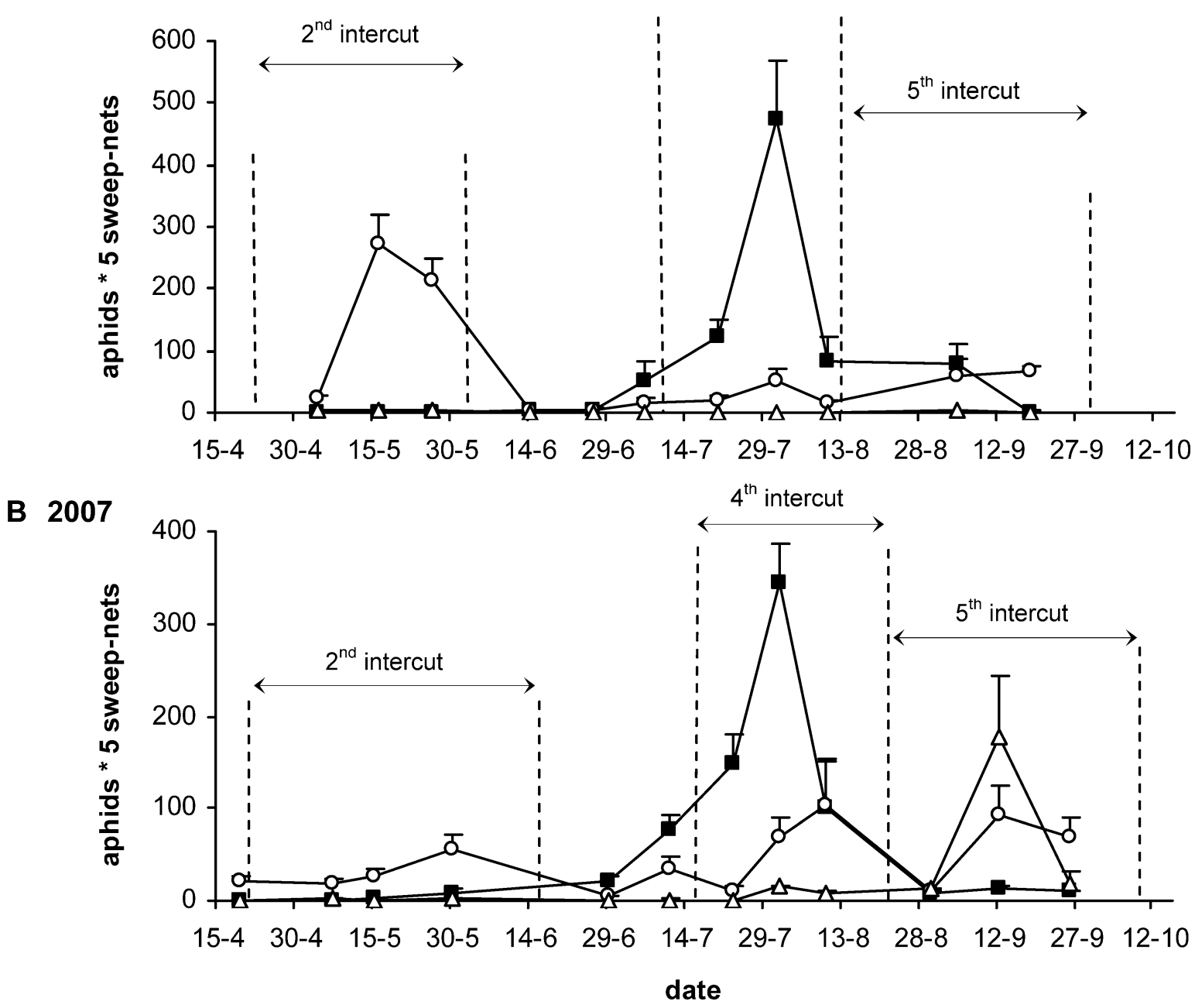

$\rightarrow-$ T. trifolii $\longrightarrow-$ A. pisum $\longrightarrow-$ A. craccivora

Fig. 1. Seasonal abundance of the prevalent aphid species during the alfalfa growing seasons of 2006 (A) and 2007 (B). Values are means $(+\mathrm{SE})$. Dashed vertical lines indicate the dates of alfalfa cutting. 

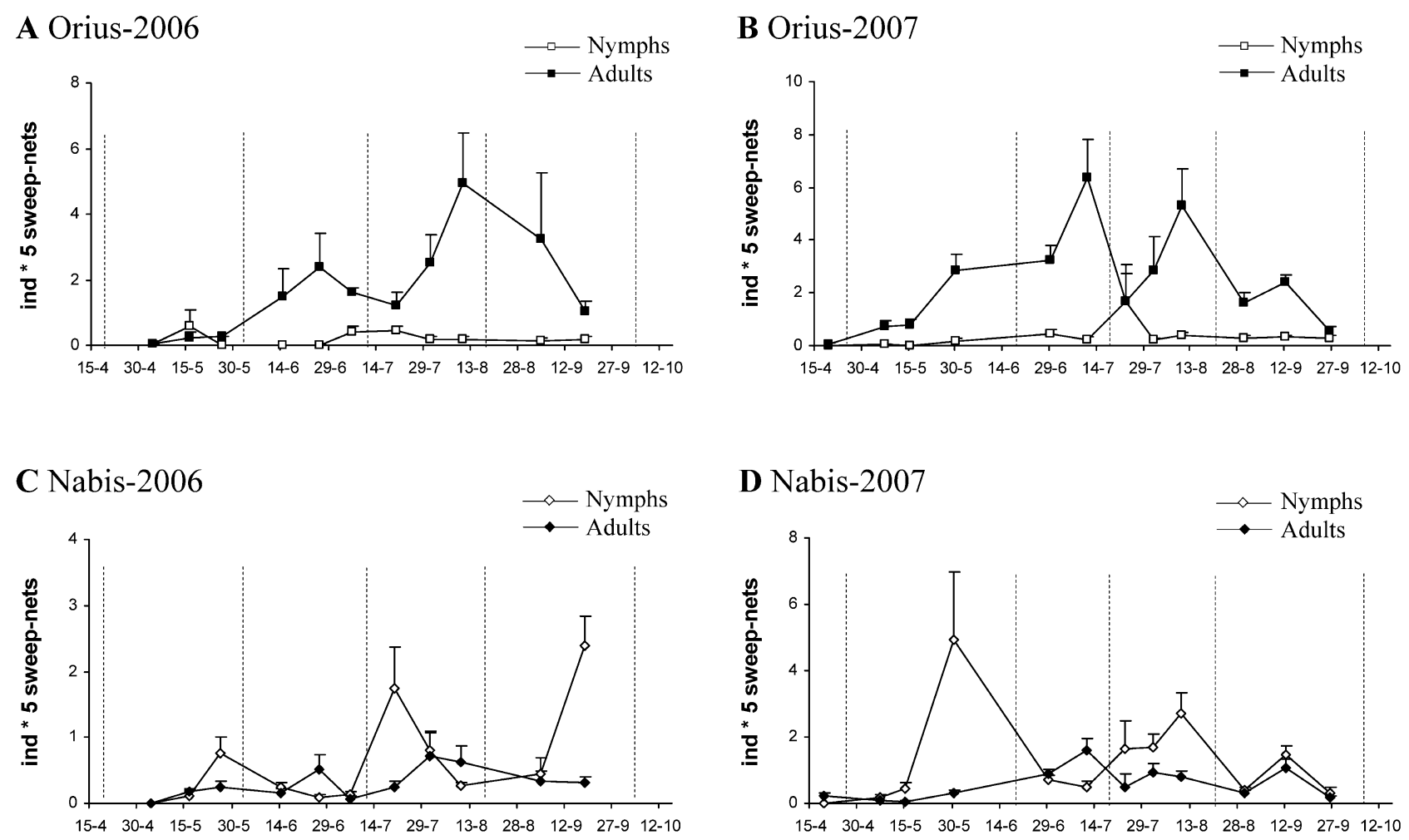

\section{E Mirids-2006}

\section{F Mirids-2007}
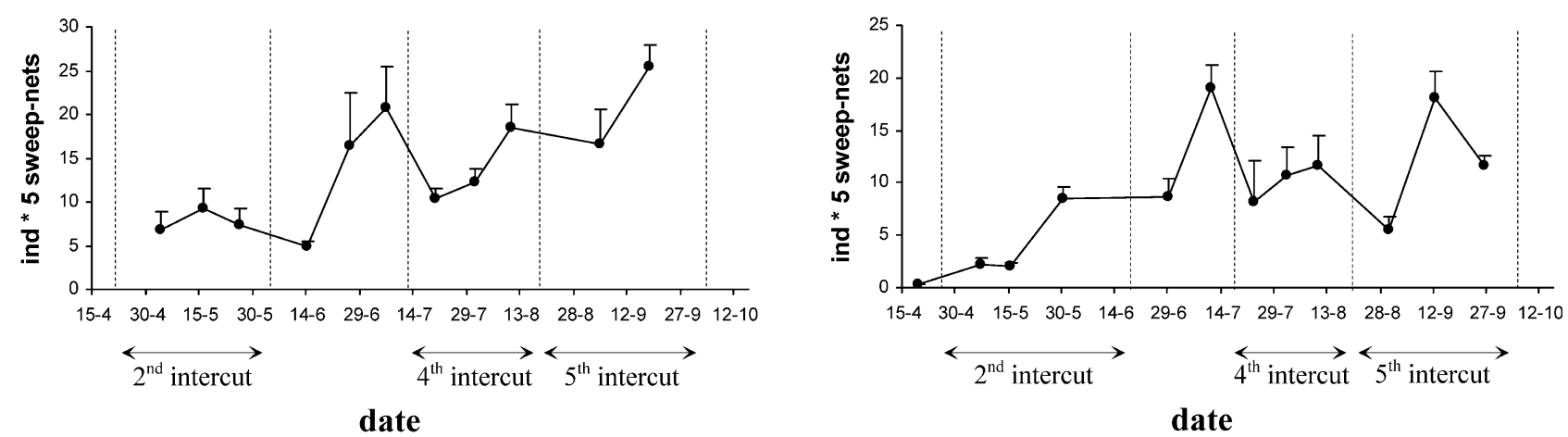

Fig. 2. Seasonal occurrence of Heteroptera predators (Orius sp., Nabis sp., and Mirids) during the alfalfa growing seasons of 2006 (A, C, E) and 2007 (B, D, F). Values are means (+ SE). Dashed vertical lines indicate the dates of alfalfa cutting. As mirids were not distinguished by species, only the seasonal abundance of all species together is presented.

\section{Predator abundance}

Heteroptera were the most abundant predatory group and represented nearly $45 \%$ of the total predators collected in 2006 and 2007 (Table 3). Predatory thrips were also very abundant, followed by Arachnida and Coleoptera. Among Heteroptera, Orius sp. (mainly Orius niger Wolf and Orius majusculus Reuter), Nabis sp. (mainly Nabis provencalis Remane) and Miridae were predominant. Coccinellidae were the prevalent coleopteran predators. Coccinella septempunctata L. was the most common species in spring, whereas in summer it was Hippodamia variegata Goeze. Sphaerophoria scripta L. was the most abundant hoverfly species and its abundance peaked in summer. Several undetermined species of spiders were present during the growing season.

Seasonal abundance of heteropterans shows that they were present throughout the growing season (Fig. 2). Adults of Orius spp. were first recorded in mid-April and reached their highest abundance in mid-July and August (during the $3^{\text {rd }}$ or $4^{\text {th }}$ intercut). However, the number of nymphs recorded was very low, probably because the sweep-net is not an efficient method for Orius sp. nymphs. Nevertheless, the results suggested that at least 3 generations of Orius spp. occurred. Adults of Nabis spp. were first recorded in mid-April and nymphs appeared later. Nymphs peaked three times during the season, first at the end of May (during the $2^{\text {nd }}$ intercut), later in midsummer (during the $4^{\text {th }}$ intercut) and finally in September 
TABLE 3. Mean (x, in insects*5 sweeps) and relative $\left(\%\right.$, in percentage) abundance of predatory insects during the $2^{\text {nd }}, 4^{\text {th }}$ and $5^{\text {th }}$ intercuts of alfalfa and during the whole alfalfa growing season in 2006 and 2007.

\begin{tabular}{|c|c|c|c|c|c|c|c|c|c|c|c|c|c|c|c|c|}
\hline \multirow{3}{*}{ Predator } & \multicolumn{8}{|c|}{$2006^{\mathrm{a}}$} & \multicolumn{8}{|c|}{$2007^{b}$} \\
\hline & \multicolumn{2}{|c|}{$2^{\text {nd }}$} & \multicolumn{2}{|c|}{$4^{\text {th }}$} & \multicolumn{2}{|c|}{$5^{\text {th }}$} & \multicolumn{2}{|c|}{ Seasonal } & \multicolumn{2}{|c|}{$2^{\text {nd }}$} & \multicolumn{2}{|c|}{$4^{\text {th }}$} & \multicolumn{2}{|c|}{$5^{\text {th }}$} & \multicolumn{2}{|c|}{ Seasonal } \\
\hline & $\mathrm{x}$ & $\%$ & $\mathrm{x}$ & $\%$ & $\mathrm{x}$ & $\%$ & $\mathrm{x}$ & $\%$ & $\mathrm{x}$ & $\%$ & $\mathrm{x}$ & $\%$ & $\mathrm{x}$ & $\%$ & $\mathrm{x}$ & $\%$ \\
\hline Heteroptera & 9.7 & 48.8 & 19.1 & 44.9 & 20.9 & 51.7 & 15.4 & 46.7 & 7.1 & 58.2 & 12.3 & 35.5 & 12.7 & 49.0 & 11.3 & 44.1 \\
\hline Orius sp. & 0.4 & 1.9 & 3.2 & 7.5 & 3.1 & 7.5 & 1.9 & 5.7 & 1.5 & 12.5 & 3.3 & 9.7 & 1.8 & 6.9 & 2.6 & 10.1 \\
\hline Nabis sp. & 0.4 & 2.1 & 1.5 & 3.5 & 1.4 & 3.6 & 0.8 & 2.4 & 2.0 & 16.5 & 2.5 & 7.4 & 1.3 & 4.8 & 1.9 & 7.1 \\
\hline Miridae & 7.8 & 38.9 & 13.7 & 32.2 & 15.6 & 38.6 & 11.8 & 35.8 & 3.1 & 25.7 & 5.4 & 15.7 & 10.0 & 38.5 & 6.5 & 24.8 \\
\hline Others & 1.2 & 5.8 & 0.7 & 1.7 & 0.8 & 2.0 & 0.9 & 2.9 & 0.4 & 3.5 & 1.0 & 2.8 & 0.2 & 0.9 & 0.5 & 2.0 \\
\hline Thysanoptera & 3.5 & 17.6 & 14.2 & 33.4 & 9.2 & 22.7 & 9.6 & 29.2 & 1.7 & 13.6 & 10.6 & 30.6 & 5.9 & 22.6 & 6.7 & 25.6 \\
\hline Aeolothripidae & 3.5 & 17.6 & 14.2 & 33.4 & 9.2 & 22.7 & 9.6 & 29.2 & 1.7 & 13.6 & 10.6 & 30.6 & 5.9 & 22.6 & 6.7 & 25.6 \\
\hline Neuroptera & $<0.1$ & 0.3 & 0.5 & 1.2 & 0.4 & 0.9 & 0.3 & 0.8 & $<0.1$ & 0.1 & 0.2 & 0.5 & $<0.1$ & 0.2 & 0.1 & 0.4 \\
\hline Chrysopidae & $<0.1$ & 0.3 & 0.5 & 1.1 & 0.4 & 0.9 & 0.2 & 0.8 & $<0.1$ & 0.1 & 0.2 & 0.5 & $<0.1$ & 0.2 & 0.1 & 0.4 \\
\hline Heme & $<0.1$ & $<0.1$ & $<0.1$ & $<0.1$ & $<0.1$ & $<0.1$ & $<0.1$ & $<0.1$ & $<0.1$ & $<0.1$ & $<0.1$ & $<0.1$ & $<0.1$ & $<0.1$ & $<0.1$ & $<0.1$ \\
\hline Coleoptera & 4.6 & 22.9 & 3.0 & 7.2 & 3.3 & 8.2 & 3.1 & 9.5 & 2.2 & 17.7 & 1.9 & 5.5 & 2.8 & 10.9 & 2.3 & 8.7 \\
\hline Coccinellidae & 4.1 & 20.5 & 2.9 & 6.8 & 3.1 & 7.7 & 2.9 & 8.6 & 1.5 & 12.2 & 1.9 & 5.4 & 2.7 & 10.3 & 1.9 & 7.4 \\
\hline H. variegata & 0.2 & 0.8 & 1.6 & 3.8 & 1.9 & 4.6 & 0.9 & & 0.3 & 2.3 & 0.8 & 2.2 & 0.7 & 2.5 & 0.6 & 2.2 \\
\hline C. septempunctata & 1.2 & 6.1 & 0.1 & 0.2 & 0.1 & 0.2 & 0.5 & 1.5 & 0.5 & 3.7 & $<0.1$ & $<0.1$ & $<0.1$ & $<0.1$ & 0.2 & 0.8 \\
\hline Larvae & 2.7 & 13.3 & 1.1 & 2.5 & 1.1 & 2.6 & 1.4 & 4.2 & 0.7 & 5.5 & 0.9 & 2.7 & 2.0 & 7.5 & 1.0 & 4.0 \\
\hline Others & $<0.1$ & 0.3 & 0.1 & 0.3 & 0.1 & 0.3 & 0.1 & 0.2 & 0.1 & 0.8 & 0.2 & 0.5 & 0.1 & 0.2 & 0.1 & 0.4 \\
\hline Cantharidae & 0.1 & 0.6 & $<0.1$ & $<0.1$ & $<0.1$ & $<0.1$ & $<0.1$ & 0.2 & $<0.1$ & $<0.1$ & $<0.1$ & 0.1 & 0.1 & 0.3 & $<0.1$ & $<0.1$ \\
\hline Staphylinidae & 0.3 & 1.3 & $<0.1$ & 0.1 & 0.1 & 0.2 & 0.1 & 0.4 & 0.6 & 4.6 & $<0.1$ & $<0.1$ & 0.1 & 0.3 & 0.3 & 1.0 \\
\hline Carabidae & 0.1 & 0.6 & 0.1 & 0.2 & 0.1 & 0.2 & 0.1 & 0. & 0.1 & 0.5 & $<0.1$ & $<0.1$ & 0.1 & 0.3 & $<0.1$ & 0.2 \\
\hline Diptera & 0.7 & 3.5 & 2.9 & 6.9 & 4.1 & 10.2 & 1.3 & 4.0 & 0.2 & 1.6 & 5.0 & 14.5 & 0.9 & 3.3 & 1.5 & 5.6 \\
\hline Syrphidae & 0.7 & 3.5 & 2.9 & 6.9 & 4.1 & 10.2 & 1.3 & 4.0 & 0.2 & 1.6 & 5.0 & 14.5 & 0.9 & 3.3 & 1.5 & 5.6 \\
\hline Arachnida & 1.4 & 6.9 & 2.8 & 6.5 & 2.6 & 6.4 & 3.3 & 9.9 & 1.1 & 8.8 & 4.7 & 13.5 & 3.6 & 14.0 & 4.0 & 15.6 \\
\hline Araneae & 1.3 & 6.4 & 2.8 & 6.5 & 2.5 & 6.0 & 3.2 & 9.8 & 1.1 & 8.8 & 4.5 & 12.8 & 3.5 & 13.4 & 3.9 & 15.2 \\
\hline Others & 0.1 & 0.5 & 0.0 & 0.0 & 0.1 & 0.4 & $<0.1$ & 0.1 & 0.0 & 0.0 & 0.2 & 0.7 & 0.1 & 0.6 & 0.1 & 0.4 \\
\hline
\end{tabular}

${ }^{a}$ Values of the $2^{\text {nd }}, 4^{\text {th }}$ and $5^{\text {th }}$ intercuts come from the average of 144 samples $(3$ sampling dates $* 4$ fields $* 4$ sectors/field $* 3$ samples/sector). Seasonal value comes from the average of 528 samples $(11$ sampling dates $) .{ }^{\text {b }}$ Values of the $2^{\text {nd }}, 4^{\text {th }}$ and $5^{\text {th }}$ intercuts come from the average of 288 samples ( 3 sampling dates $* 8$ fields $* 4$ sectors/field $* 3$ samples/sector). Seasonal value comes from the average of 1152 samples (12 sampling dates).

(during the $5^{\text {th }}$ intercut); similarly, three peaks of adults were also evident. These results suggest that Nabis spp. had three generations during the growing season. Two main peaks of mirid populations occurred during the $3^{\text {rd }}$ and the $5^{\text {th }}$ intercuts but other lower peaks were also recorded during the $2^{\text {nd }}$ and the $4^{\text {th }}$ intercuts.

\section{Predator-aphid relationships}

These relationships were studied during the $2^{\text {nd }}, 4^{\text {th }}$ and $5^{\text {th }}$ intercuts, when the aphid populations peaked. Relationships with no or one date lag were studied through the $2^{\text {nd }}$ and $4^{\text {th }}$ intercuts in 2006 and 2007. For the $5^{\text {th }}$ intercut, predator-prey relationships were analyzed only in 2007 since in 2006 no aphid species clearly peaked at that time.

Analysis with no lag

In the $2^{\text {nd }}$ intercut in 2007 , all the heteropteran predators showed positive correlations with the prevalent aphid species, A. pisum, but no correlation was observed in 2006 (Table 4a). In 2007, correlations accounted for less than $50 \%$ of the observed variation, that of Miridae being the greatest. When the multiple regression analysis was performed, taking into account other prey in addition to A. pisum, there was also an effect of year, but different predator-prey relationships appeared and a greater per- centage of the observed variation was explained (Table 5a). Adults of Orius sp. did not correlate with any potential prey in 2006 but in 2007 their numbers increased with numbers of leafhoppers and alfalfa weevil larvae $\left(R^{2}=\right.$ 0.65 ), whereas inclusion of $A$. pisum did not significantly improve the explained variation. Quite a similar pattern was observed with adults of Nabis sp.; in this case, the numbers of Nabis sp. adults increased with the numbers of leafhoppers and mirid adults $\left(R^{2}=0.67\right)$. Nymphs of Nabis sp. were correlated with thrips in $2006\left(R^{2}=0.35\right)$ but in 2007 showed a good correlation with the other aphid species (A. craccivora $+T$. trifolii) in addition to $A$. pisum $\left(R^{2}=0.73\right)$. No effect of the year was found for Miridae and the numbers of this predatory group increased with those of $A$. pisum and leafhoppers $\left(R^{2}=\right.$ $0.59)$ when data for both years were pooled.

Higher correlations and more consistent annual relationships were found for the specialist aphid predators $C$. septempunctata and for larvae of Coccinellidae (Table 4a). Adults of $C$. septempunctata showed a numerical relationship only with A. pisum and not with other potential prey, whereas numbers of coccinellid larvae increased with numbers of $A$. pisum and other soft-bodied prey, but 
TABLE 4. Values of $R^{2}$ and $P$ of the no-lag and one sampling date lag regression between the most abundant Heteroptera or Coccinellidae and the prevalent aphid species during the $2^{\text {nd }}(A$. pisum $), 4^{\text {th }}\left(\right.$ T. trifolii) and $5^{\text {th }}($ A. craccivora $)$ alfalfa intercuts in 2006 and 2007.

\begin{tabular}{|c|c|c|c|c|c|}
\hline \multirow{3}{*}{$\begin{array}{l}\text { Intercut } \\
\text { Prevalent aphid species }\end{array}$} & \multicolumn{2}{|c|}{$2^{\text {nd }}$} & \multicolumn{2}{|c|}{$4^{\text {th }}$} & \multirow{3}{*}{$\begin{array}{c}5^{\text {th }} \\
{\text { A. } \text { craccivora }^{\mathrm{c}}}^{\mathrm{c}} \\
2007\end{array}$} \\
\hline & \multicolumn{2}{|c|}{ A. pisum ${ }^{\mathrm{a}}$} & \multicolumn{2}{|c|}{ T. trifolii ${ }^{\mathrm{b}}$} & \\
\hline & 2006 & 2007 & 2006 & 2007 & \\
\hline Regression parameters & $R^{2}(P)^{\mathrm{d}}$ & $R^{2}(P)$ & $R^{2}(P)$ & $R^{2}(P)$ & $R^{2}(P)$ \\
\hline \multicolumn{6}{|l|}{ (a) No lag } \\
\hline \multicolumn{6}{|l|}{ Heteroptera } \\
\hline Orius sp. adults & $0.05(\mathrm{NS})$ & $0.29(<0.01)$ & $0.03(\mathrm{NS})$ & $<0.01(\mathrm{NS})$ & $0.10(\mathrm{NS})$ \\
\hline Nabis sp. adults & $0.26(\mathrm{NS})$ & $0.38(<0.01)$ & $<0.01$ (NS) & $0.02(\mathrm{NS})$ & $0.14(\mathrm{NS})$ \\
\hline Nabis sp. nymphs & 0.28 (NS) & $0.33(<0.01)$ & $<0.01(\mathrm{NS})$ & $0.03(\mathrm{NS})$ & $0.12(\mathrm{NS})$ \\
\hline Mirids Total & $0.31(\mathrm{NS})$ & $0.46(<0.01)$ & $0.04(\mathrm{NS})$ & $<0.01(\mathrm{NS})$ & $0.08(\mathrm{NS})$ \\
\hline \multicolumn{6}{|l|}{ Coccinellidae } \\
\hline C. septempunctata & $0.56(<0.01)$ & $0.55(<0.01)$ & - & - & - \\
\hline Larvae & $0.38(0.03)$ & $0.65(<0.01)$ & $0.05(\mathrm{NS})$ & $0.12(\mathrm{NS})$ & 0.05 (NS) \\
\hline H. variegata & $-{ }^{\mathrm{e}}$ & - & 0.09 (NS) & 0.05 (NS) & $0.32(<0.01)$ \\
\hline \multicolumn{6}{|l|}{ (b) One sampling date lag } \\
\hline \multicolumn{6}{|l|}{ Heteroptera } \\
\hline Orius sp. adults & $0.03(\mathrm{NS})$ & $0.02(\mathrm{NS})$ & $<0.01(\mathrm{NS})$ & $0.02(\mathrm{NS})$ & $0.20(\mathrm{NS})$ \\
\hline Nabis sp. adults & $0.03(\mathrm{NS})$ & $0.01(\mathrm{NS})$ & $<0.01(\mathrm{NS})$ & $0.03(\mathrm{NS})$ & $0.21(\mathrm{NS})$ \\
\hline Nabis sp. nymphs & $0.71(<0.01)$ & $<0.01(\mathrm{NS})$ & $0.44(\mathrm{NS})$ & $<0.01(\mathrm{NS})$ & $0.50(<0.01)$ \\
\hline Mirids Total & $0.01(\mathrm{NS})$ & $0.04(\mathrm{NS})$ & $0.06(\mathrm{NS})$ & $0.11(\mathrm{NS})$ & $0.23(\mathrm{NS})$ \\
\hline \multicolumn{6}{|l|}{ Coccinellidae } \\
\hline C. septempunctata & $0.07(\mathrm{NS})$ & $0.12(\mathrm{NS})$ & - & - & - \\
\hline Larvae & $0.72(<0.01)$ & $0.13(\mathrm{NS})$ & 0.18 (NS) & $0.03(\mathrm{NS})$ & $0.10(\mathrm{NS})$ \\
\hline H. variegata & - & - & 0.38 (NS) & $0.13(\mathrm{NS})$ & $0.04(\mathrm{NS})$ \\
\hline
\end{tabular}

a2006: no lag, $\mathrm{n}=12$, one sampling date lag, $\mathrm{n}=8$; 2007: lag, $\mathrm{n}=24$, one sampling date lag, $\mathrm{n}=16$; ${ }^{\mathrm{b}} 2006$ : no lag, $\mathrm{n}=12$, one sampling date lag, $\mathrm{n}=8 ; 2007$ : lag, $\mathrm{n}=20$, one sampling date lag, $\mathrm{n}=13 ;{ }^{c} 2007$ : $\mathrm{no}$ lag, $\mathrm{n}=21$; one sampling date lag, $\mathrm{n}=14 ;{ }^{\mathrm{d}} \mathrm{NS}=P$ $>0.05 ;{ }^{\mathrm{e}}-=$ not included in the analysis.

were negatively correlated with numbers of alfalfa weevil larvae.

In contrast, when correlations of Heteroptera with the prevalent aphid species during the $4^{\text {th }}$ intercut, $T$. trifolii, were calculated, no response of any heteropteran or coccinellid to T. trifolii were observed (Table 4a). Multiple regression analysis performed, taking into account other potential prey in addition to T. trifolii, showed that heteropterans mainly had relationships with prey other than aphids (Table 5b). Adults of Orius sp. and nymphs of Nabis sp. were numerically related to other soft-bodied potential preys, whereas adults of nabids were related to nymphs of mirids. In all these cases $R^{2}$ values were below 0.30 (Table 5b). The numerical response of mirids depended on the year, no response was observed in 2006, but in 2007 numbers of mirids increased with those of thrips and other soft-bodied prey. No numerical relationship between $H$. variegata, the most abundant coccinellid during the 4th intercut, and any of the preys considered could be found. Ladybird larvae were numerically related to leafhoppers but not to aphids.

As in the $4^{\text {th }}$ intercut, heteropterans did not increase their numbers in concert with the prevalent aphid species during the $5^{\text {th }}$ intercut (Table $4 \mathrm{a}$ ). The multiple regression analysis (Table 5c) showed that numbers of nabid adults increased with mirid nymphs, whereas nabid nymphs were numerically related to leafhoppers and to aphids other than A. craccivora, with these two prey groups explaining a high percentage of the observed variation. Thrips were strongly related to mirids.

$H$. variegata, the most abundant coccinellid during the $5^{\text {th }}$ intercut, increased its population in concert with $A$. craccivora (Table 4a). However, the multiple regression analysis showed that the abundance of $H$. variegata was more related to non-prevalent aphid species (A. pisum mainly) and to other soft-bodied herbivores since the inclusion of $A$. craccivora (the prevalent species) in the analysis did not explain any additional variation. Larvae of coccinellids also showed a numerical relationship with thrips and aphids other than the prevalent species (Table 5c).

Analysis with a lag of one sampling date in predator abundance

No significant lag correlations were found between adults of Orius sp. and Nabis sp. or mirids and A. pisum in the $2^{\text {nd }}$ intercut but this kind of relationship appeared for nymphs of Nabis sp. in 2006 (Table 4b). When the multiple regression analysis was performed, the year was not significant and the increase in numbers of Nabis sp. could not be associated with any potential prey, whereas adults of Orius sp. were associated with leafhoppers $\left(R^{2}=\right.$ $0.31, P=0.0047)$ and mirids with larvae of alfalfa weevil $\left(R^{2}=0.30, P=0.0060\right)$. On the other hand, no lag correlations were found between $C$. septempunctata and aphids but they were found between larvae of Coccinellidae and A. pisum $\left(R^{2}=0.73, P<0.0001\right)$ independently of the year (Table $4 b)$. 
TABLE 5. Forward multiple regression analysis for aphid predator abundance. Prey variables are listed in decreasing order of their contribution to the model $R^{2}$. (a) $2^{\text {nd }}$ intercut, $A$. pisum was the prevalent aphid species; (b) $4^{\text {th }}$ intercut, $T$. trifolii was the prevalent aphid species; (c) $5^{\text {th }}$ intercut, $A$. craccivora was the prevalent aphid species.

\begin{tabular}{|c|c|c|c|}
\hline Dependent variable (Predator) & Independent variables (Prey) included & $R^{2}$ & $P$ \\
\hline \multicolumn{4}{|l|}{ (a) $2^{\text {nd }}$ intercut } \\
\hline \multicolumn{4}{|l|}{ Heteroptera } \\
\hline Orius sp. Adults & Year & 0.2630 & 0.0014 \\
\hline 2006 & $-{ }^{\mathrm{c}}$ & - & - \\
\hline 2007 & Leafhoppers + alfalfa weevil larvae & 0.6466 & $<0.0001$ \\
\hline Nabis sp. Adults & Year & 0.1397 & 0.0078 \\
\hline 2006 & $-{ }^{c}$ & - & - \\
\hline 2007 & Leafhoppers + mirid Adults & 0.6653 & $<0.0001$ \\
\hline Nabis sp. Nymphs & Year & 0.0563 & 0.0436 \\
\hline 2006 & Thrips & 0.3536 & 0.0414 \\
\hline 2007 & Other aphids ${ }^{\mathrm{a}}+A$. pisum & 0.7286 & $<0.0001$ \\
\hline Mirids Total & A. pisum + leafhoppers & 0.5932 & $<0.0001$ \\
\hline \multicolumn{4}{|l|}{ Coccinellidae } \\
\hline C. septempunctata & A. pisum & 0.6231 & $<0.0001$ \\
\hline Larvae & A. pisum - alfalfa weevil larvae + soft-bodied $^{\mathrm{b}}$ & 0.7012 & $<0.0001$ \\
\hline \multicolumn{4}{|l|}{ (b) $4^{\text {th }}$ intercut } \\
\hline \multicolumn{4}{|l|}{ Heteroptera } \\
\hline Orius sp. adults & Soft-bodied ${ }^{\mathrm{b}}$ & 0.2737 & 0.0021 \\
\hline Nabis sp. adults & Mirid nymphs & 0.2749 & 0.0021 \\
\hline Nabis sp. nymphs & Soft-bodied ${ }^{\mathrm{b}}$ & 0.2192 & 0.0069 \\
\hline Mirids Total & Year & 0.2275 & 0.0058 \\
\hline 2006 & $-{ }^{c}$ & - & - \\
\hline 2007 & Thrips + soft-bodied $^{\mathrm{b}}$ & 0.7737 & $<0.0001$ \\
\hline \multicolumn{4}{|l|}{ Coccinellidae } \\
\hline H. variegata & Year & 0.1631 & 0.0219 \\
\hline 2006 & - & - & - \\
\hline 2007 & - & - & - \\
\hline Larvae & Leafhoppers & 0.1994 & 0.0104 \\
\hline \multicolumn{4}{|l|}{ (c) $5^{\text {th }}$ intercut (only 2007 ) } \\
\hline \multicolumn{4}{|l|}{ Heteroptera } \\
\hline Orius sp. adults & $-{ }^{c}$ & - & - \\
\hline Nabis sp. adults & Mirid nymphs & 0.2528 & 0.0202 \\
\hline Nabis sp. nymphs & Leafhoppers + other aphids ${ }^{\mathrm{d}}$ & 0.7959 & $<0.0001$ \\
\hline Mirids Total & Thrips & 0.6839 & $<0.0001$ \\
\hline \multicolumn{4}{|l|}{ Coccinellidae } \\
\hline H. variegata & Other aphids ${ }^{\mathrm{d}}+$ soft-bodied $^{\mathrm{b}}$ & 0.6553 & $<0.0001$ \\
\hline Larvae & Thrips + other aphids ${ }^{\mathrm{d}}$ & 0.4460 & 0.0049 \\
\hline
\end{tabular}

${ }^{\mathrm{a}}$ Other aphids: (A. craccivora + T. trifolii); ${ }^{\mathrm{b}}$ soft-bodied: planthoppers + Collembola + lepidopteran larvae; ${ }^{\mathrm{c}}-$ no related prey variables were found; ${ }^{\mathrm{d}}$ other aphids: (A. pisum + T. trifolii).

Heteropterans did not show lag correlations with T. trifolii during the $4^{\text {th }}$ intercut, nor did coccinellids (Table $4 \mathrm{~b})$. Multiple regression revealed correlations between adults of Orius sp. and leafhoppers $\left(R^{2}=0.27, P=\right.$ $0.0155)$, between nabid nymphs and mirid nymphs in $2007\left(R^{2}=0.34, P=0.0354\right)$, and between mirids and leafhoppers in $2007\left(R^{2}=0.52, P=0.0056\right)$. The coccinellid $H$. variegata was found to be correlated with thrips $\left(R^{2}=0.21, P=0.0361\right)$ and ladybird larvae were not correlated with any potential prey.

During the $5^{\text {th }}$ intercut, adults of Orius sp., nabid adults and mirids did not show lagged numerical responses to $A$. craccivora and nabid nymphs showed a negative response (Table 4b). Multiple regression analysis indicated that Orius sp., nabid adults and mirids were related to thrips and soft-bodied preys $\left(R^{2}=0.60, P=0.0067, R^{2}\right.$ $=0.62, P=0.0055$ and $R^{2}=0.76, P=0.0004$, respectively) and nabid nymphs to other aphids $\left(R^{2}=0.65, P=\right.$
0.0005). Coccinellids did not show lag relationships with any potential prey.

\section{DISCUSSION}

Composition and seasonal abundance of aphid species observed during this study closely agree with previous reports from Spain (Pons et al., 2005), although our records come from an inter-mountain area where alfalfa is a relatively recent crop. Two population peaks characterize the aphid seasonal abundance. The first peak occurs in spring during the $2^{\text {nd }}$ intercut with $A$. pisum as the dominant species and the second peak occurs during the $4^{\text {th }}$ intercut with $T$. trifolii as the dominant species. Aphid densities in these peaks were below the economic thresholds for this region (Pons, 2002). The extremely low densities of $A$. craccivora in 2006 do not allow us to make any inference with respect to the importance of this species as a pest in the study area. 
The predator complexes also parallel previous findings in other areas of NE Spain (Pons et al., 2005), where heteropterans are the most abundant predators, especially Orius spp., Nabis spp. and mirids. In our study, these heteropterans were present in alfalfa stands throughout the season and had at least 3 generations. Alfalfa cutting does not seem to affect them negatively and populations increase or recover quickly after cutting (Fig. 2). This capacity to remain or re-colonize the crop after "catastrophic" agricultural practices, such as cutting, is important for generalist predators (Symondson et al., 2002) and a desirable characteristic for biological control agents in ephemeral crops (Wiedenmann \& Smith, 1997).

Density-dependent processes, including the functional and numerical responses, are determinant factors for predator efficacy in controlling pests (Coll \& Ridgway, 1995). Whereas several heteropteran predators show type II functional responses to aphids (Foglar et al., 1990; Alvarado et al., 1997; Rutledge \& O’Neil, 2005), numerical responses are less well known. Weak numerical responses of heteropteran predators to alfalfa aphids in field studies have been reported by both Elliot et al. (2002) in the USA and Pons et al. (2005) in Spain. Whereas Elliot et al. (2002) described the numerical response of adults of Nabis americoferus Carayon, Pons et al. (2005) did so for adults and nymphs of $N$. provencalis and for adults of Orius sp. However, in these reports the whole season and all aphid species were considered together rather than separately for periods in which different aphid species predominated, as done in the present study.

Although significant coefficients of correlation between populations densities do not necessary imply cause-effect relationships, significant field correlations between predators and prey numbers may give a preliminary indication of a potential impact of the predator on prey (Naranjo \& Hagler, 1988). Therefore, our analyses are exploratory and present as a first step towards determining causeeffect relationships.

The results presented here show that heteropterans respond to aphids only in some cases and that the response is immediate rather than lagged. There was no immediate or lagged numerical response of heteropterans to the prevalent aphid species during the $4^{\text {th }}$ and the $5^{\text {th }}$ intercut. These results agree with a large body of literature on generalist predators, that suggest they are unlikely to impact pests once these increase exponentially (Murdoch et al., 1985; Symondson et al., 2002; Harwood \& Obrycky, 2005), and suggest the same is true for heteropterans (Yeargan, 1998; Harwood et al., 2007). However, there was a no-lag positive response for Orius sp., Nabis sp and mirids in 2007 and a lag response of Nabis sp. nymphs in 2006 to $A$. pisum, the prevalent aphid species at the beginning of the alfalfa growing season, indicating that heteropterans track aphid populations at the beginning of the season when aphid populations are low. This was also recorded by Desneux et al. (2006) and Harwood et al. (2007), who found $O$. insidiosus targeting $A$. glycines early in the season when aphid density was extremely low and concluded that $O$. insidiosus was a valuable natural enemy of $A$. glycines in soybean agroecosystems. On the other hand, O. majusculus and Orius laevigatus (Fieber) have been proposed for biological control of Aphis gossypii Glover and Macrosiphum euphorbiae (Thomas) in cucumbers (Alvarado et al., 1997). However, results of the multiple regression analysis suggest that adults of Orius sp. may have a preference for leafhoppers or alfalfa weevil larvae rather than aphids in alfalfa. A similar pattern may be applied for adults of Nabis sp. On the other hand, nymphs of Nabis sp. showed numerical responses to $A$. pisum in the multiple regression analysis, not only during the second intercut but also during the $5^{\text {th }}$, when it became the main component of the other aphid species complex (Fig. 1). Moreover, there was also a positive correlation with aphids other than $A$. pisum during the $2^{\text {nd }}$ intercut. These results emphasize the role of nabids as aphid predators in alfalfa, reported by Elliot et al. (2002) and Pons et al. (2005), especially at low aphid densities. Mirid numbers increased with those of $A$. pisum in the $2^{\text {nd }}$ intercut, reflecting mirid aggregation in fields where $A$. pisum occurred. Although the dietary heterogeneity of the mirids in the study may mask the role of these predators in aphid control they should not be discounted as potentially good predators of alfalfa aphids at the beginning of the growing season.

Our results show that heteropteran predators responded numerically to several non-aphid prey, all of which remained in low densities. There were aggregative responses with no lag and a lag of one sampling date of Orius sp., Nabis sp. and mirids to leafhoppers, thrips and other soft-bodied herbivores. These responses to densities of non-aphid prey favour the continued presence of predators in the crop (Evans \& Toler, 2007) in addition to their ability for using some plant food resources. Moreover, there were aggregative responses of adults of Nabis $\mathrm{sp}$. to mirids in the three intercuts considered. Because nabids are known to prey on mirids (Lattin, 1989; Braman, 2000), our results suggest that mirids may be an important prey for adults of nabids in alfalfa, and that intraguild predation occurs.

Although numerical responses of coccinellids to aphid density have been reported in alfalfa (Neuenschwander et al., 1975; Frazer et al., 1981; Elliot et al., 2002; Evans \& Toler, 2007), we only found it at low aphid densities. Aphids interact with several predatory species, including heteropterans and coccinellids, but also with parasitoids and fungal pathogens which may have great influence in regulating aphid populations in alfalfa when densities are high, as reported by Gutierrez et al. (2008) in California.

In summary, in our study heteropterans were present in alfalfa stands throughout the season, responded numerically to aphids when these were at low density and also responded to several other prey species that remained in low densities throughout the season, alone or together with aphids. These characteristics suggest that heteropterans: (1) May help to delay and prevent the build-up of aphids - particularly A. pisum at the beginning of the crop 
growing season - and that of other potential pest populations. (2) Respond to the varying local densities of several prey species, which help them to persist in the crop even in periods with no aphids. (3) Are able to remain on alfalfa in spite of cutting, or re-colonize it soon after cutting, and to aggregate on potential pests when they colonize the crop again - a desirable characteristic for biological control in ephemeral crops.

ACKNOWLEDGEMENTS. We thank L. Xanxo and A. Solans from the Cooperativa Pirenaica de La Seu d'Urgell for field selection and agronomic technical assistance. We also thank B. Baraibar and N. Pujol for their help in counting insects, I. Romagosa for statistical support and two anonymous referees that with their comments improved the manuscript. This research was funded by the Cooperativa Pirenaica de La Seu d'Urgell.

\section{REFERENCES}

Albajes R. \& Alomar O. 1999: Current and potential use of polyphagous predators. In Albajes R., Gullino M.L., van Lenteren J.C. \& Elad Y. (eds): Integrated Pest Disease Management in Greenhouse Crops. Kluwer, Dordrecht, pp. 265-275.

Alvarado P., Balta O. \& Alomar O. 1997: Efficiency of four Heteroptera as predators of Aphis gossypii and Macrosiphum euphorbiae (Hom.: Aphididae). Entomophaga 42: 215-226.

Arnó J., Roig J. \& Riudavets J. 2008: Evaluation of Orius majusculus and $\mathrm{O}$. laevigatus as predators of Bemisia tabaci and estimation of their prey preference. Biol. Contr. 44: 1-6.

Braman K. 2000: Damsel bugs (Nabidae). In Schaefer C.W. \& Panizzi A.R. (eds): Heteroptera of Economic Importance. CRC Press LLC, Boca Raton, FL, pp. 639-656.

Coll M. \& Ridgway R.L. 1995: Functional and numerical responses of Orius insidiosus (Heteroptera: Anthocoridae) to its prey in different vegetable crops. Ann. Entomol. Soc. Am. 88: $732-738$.

Coll M. \& Ruberson J.R. 1998: Predatory Heteroptera: an important yet neglected group of natural enemies. In Coll M. \& Ruberson J.R. (eds): Predatory Heteroptera: Their Ecology and Use in Biological Control. Thomas Say Publications in Entomology: Proceedings. Entomological Society of America, Lanham, MA, pp. 1-6.

Desneux N., O’Neil R.J. \& Yoo H.J.S. 2006: Suppression of population growth of the soybean aphid, Aphis glycines Matsamura, by predators: The identification of a key predator and the effects of prey dispersion, predator abundance, and temperature. Environ. Entomol. 35: 1342-1349.

Eizaguirre M., XanXo L. \& Pons X. 2005: Importance and control of soil pests in silage maize in the highlands of the Pyrenees, north-east Spain. Crop Prot. 24: 549-555.

Elliot N.C., Kieckhefer R.W., Michels G.J. JR. \& Giles K.L. 2002: Predator abundance in alfalfa fields in relation to aphids, within-field vegetation, and landscape matrix. Environ. Entomol. 31: 253-260.

Evans E.W. \& Toler T.R. 2007: Aggregation of polyphagous predators in response to multiple prey: ladybirds (Coleoptera: Coccinellidae) foraging in alfalfa. Popul. Ecol. 49: 29-36.

Foglar H., Malausa J.C. \& Wajnberg E. 1990: The functional response and preference of Macrolophus caliginosus (Heteroptera: Miridae) for two of its prey: Myzus persicae and Tetranychus urticae. Entomophaga 35: 465-474.

Frazer B.B., Gilbert N., Nealis V. \& Raworth D.A. 1981: Control of aphid densities by a complex of predators. Can. Entomol. 31: 253-260.
Gutierrez A.P., Ponti L., D’Oultremont T. \& Ellis C.K. 2008: Climatic change effects on poikilotherm tritrophic interactions. Climat. Change 87: 167-192.

HARWOOD J.D. \& OBRYCKI J.J. 2005: Quantifying aphid predation rates of generalist predators in the field. Eur. J. Entomol. 102: 335-350.

Harwood J.D., Desneux N., Yoo H.J.S., Rowley D.L., GreenStONE M.H., OBRYCKI J.J. \& O'NeIL R.J. 2007: Tracking the role of alternative prey in soybean aphid predation by Orius insidiosus: a molecular approach. Mol. Ecol. 16: 4390-4400.

KIDD N.A.C \& Jervis M.A. 1996: Population dynamics. In Jervis M.A. \& Kidd N.A.C. (eds): Insect Natural Enemies, Practical Approaches to their Study and Evaluation. Chapman \& Hall, London, pp. 317-318.

Lattin J.D. 1989: Bionomics of Nabidae. Annu. Rev. Entomol. 34: 383-400.

Little T.M. \& Hills F.J. 1972: Statistical Methods in Agricultural Research. Agricultural Extension, University of California, Davis, CA, 242 pp.

Murdoch W.W., Chesson J. \& Chesson P.L. 1985: Biological control in theory and practice. Am. Nat. 125: 344-366.

NARANJo S.E.W. \& Hagler J.R. 1998: Characterizing and estimating the effect of Heteroptera predation. In Coll M. \& Ruberson J.R. (eds): Predatory Heteroptera: Their Ecology and Use in Biological Control. Thomas Say Publications in Entomology: Proceedings. Entomological Society of America, Lanham, MA, pp. 171-197.

Neuenschwander P., Hagen K.S. \& Smith R.F. 1975: Predation on aphids in California's alfalfa fields. Hilgardia 43: 53-78.

NúÑEZ E. 2002: La Alfalfa como Reservorio de Enemigos Naturales. $\mathrm{PhD}$ thesis, Universitat de Lleida, Lleida, $240 \mathrm{pp}$.

Pons X. 2002: Niveles poblacionales de pulgones en alfalfa libre de tratamientos aficidas. In Chocarro C., Santiveri F., Fanlo R., Bovet I. \& Lloveras J. (eds): Producción de Pastos, Forrajes y Céspedes. Ediciones de la Universidad de Lleida, Lleida, pp. 349-353.

Pons X., NúÑez E., Lumbierres B. \& Albajes R. 2005: Epigeal aphidophagous predators and the role of alfalfa as a reservoir of aphid predators for arable crops. Eur. J. Entomol. 102: 519-525.

Ruberson J.R. \& Coll M. 1998: Research needs for the predaceous Heteroptera. In Coll M. \& Ruberson J.R. (eds): Predatory Heteroptera: Their Ecology and Use in Biological Control. Thomas Say Publications in Entomology: Proceedings. Entomological Society of America, Lanham, MA, pp. 225-233.

Rutledge C.E. \& O’Neil R.J. 2005: Orius insidiosus (Say) as predator of the soybean aphid, Aphis glycines Matsamura. Biol. Contr. 33: 56-64.

SAS Institute 2000: SAS/STAT User's Guide. Version 8. SAS Institute, Cary, NC.

Schaefer C.W. \& Panizzi A.R. (eds) 2000: Heteroptera of Economic Importance. CRC Press, Boca Raton, FL, 828 pp.

Symondson W.O.C., Sunderland K.D. \& Greenstone M.H. 2002: Can generalist predators be effective biocontrol agents? Annu. Rev. Entomol. 47: 561-594.

Yeargan K.V. 1998: Predatory Heteroptera in North American Agroecosystems: an overview. In Coll M. \& Ruberson J.R. (eds): Predatory Heteroptera: Their Ecology and Use in Biological Control. Thomas Say Publications in Entomology: Proceedings. Entomological Society of America, Lanham, MA, pp. 7-19.

WiedenMANn R.N. \& SMith J.W. JR. 1997: Attributes of natural enemies in ephemeral crop habitats. Biol. Contr. 10: 16-22.

Xu X., Borgemeister C. \& Poehling H.-M. 2006: Interactions in the biological control of the western flower thrips Frank- 
liniella occidentalis (Pergande) and the two-spotted spider mite Tetranychus urticae Koch by the predatory bug Orius insidiosus Say on beans. Biol. Contr. 36: 57-64.

Received January 29, 2009; revised and accepted April 6, 2009 